\title{
Saying No: A Brief Compendium and Sometimes a Workbook with Blank Spaces
}

\section{Sandra McPherson}

1

There is an art to writing in the negative just as writing affirmatively is an art. Once in a while a poet builds his style on his use of denials. W. S. Merwin is one of these poets. "The Owl" is about "You who are never there." There is frustration: "that is the sound of my running/ the plea/ plea that it makes/ which you will never hear" ("Words from a Totem Animal"). And from that same poem these: "I might have been right/ not who I am/ but alright/ among the walls among the reasons/ not even waiting/ not seen"; "there are no names for the rivers"; "Caught again and held again/ again I am not a blessing"; "There are no stars/ there is no grief/ I will never arrive"; "I can turn myself toward the other joys and their lights / but not find them/ I can put my words into the mouths/ of spirits/ but they will not say them"; "I dreamed I had no nails/ no hair/ I had lost one of the senses/ not sure which"; and more. Hardly a poem passes in which Merwin does not make use of a negative image: "riderless horses no messages" ("Inscription Facing Western Sea"); "every minute is one of the doors/ that never opened" ("Sunset after Rain"). He is researching the erasures of the universe but I have to admit my first thought was that he took the easy way out by trying to make a dead end into something profound. I felt he chose vague words to describe the vague, mysterious phrases to evoke the mysterious. The negatives still do not add to my enjoyment of the poems, but they do provide the enjoyable game of pursuing the negative aesthetic.

From "I Am Vertical":

But I would rather be horizontal.

I am not a tree with my root in the soil

Sucking up minerals and motherly love

So that each March I may gleam into leaf,

Nor am I the beauty of a garden bed

Attracting my share of Ahs and spectacularly painted,

Unknowing I must soon unpetal. 
Compared with me, a tree is immortal

And a flower-head not tall, but more startling,

And I want the one's longevity and the other's daring.

"Study of Two Pears":

I

Opusculum paedagogum.

The pears are not viols,

Nudes or bottles.

They resemble nothing else.

II

They are yellow forms

Composed of curves

Bulging toward the base.

They are touched red.

III

They are not flat surfaces

Having curved outlines

They are round

Tapering toward the top.

IV

In the way they are modelled

There are bits of blue.

A hard dry leaf hangs

From the stem.

V

The yellow glistens.

It glistens with various yellows,

Citrons, oranges and greens

Flowering over the skin.

VI

The shadows of the pears

Are blobs on the green cloth.

The pears are not seen

As the observer wills.

Plath and Stevens, though ostensibly denying, give us abundance. Their lines are gifts to the reader (and to themselves) of all the many things which the subject is not. A lesser poet might offer in return for his nos and nots a sense of the strange but a stingy strange-the uncreated.

From Merwin's “The Asians Dying”:

Pain the horizon

Remains 
Overhead the seasons rock

They are paper bells

Calling to nothing living

The possessers move everywhere under Death their star

Like columns of smoke they advance into the shadows

Like thin flames with no light

They with no past

And fire their only future

How is it similar to this?

The weather wept, and all the trees bent down;

Bent down their birds: the light waves took the waves;

Each single substance gliddered to the stare;

Each vision purely, purely was its own:

-There was no light; there was no light at all;

(Roethke's "The Shimmer of Evil")

\section{4}

A poem of William Stafford's applies itself to the problem of perceiving the unknown:

Connections

Ours is a low, curst, under-swamp land

the raccoon puts his hand in,

gazing through his mask for tendrils

that will hold it all together.

No touch can find that thread, it is too small.

Sometimes we think we learn its course-

through evidence no court allows

a sneeze may glimpse us Paradise.

But ways without a surface we can find

flash through the mask only by surprise-

a touch of mud, a raccoon smile.

And if we purify the pond, the lilies die.

The concrete is strange enough, the physical is the paradoxical mirror which, used surprisingly, implies unknown reality.

Louise Bogan, in "Medusa": 
The water will always fall, and will not fall,

And the tipped bell make no sound.

My eyes on the yellow dust, that was lifting in the wind, And does not drift away.

This by Fudaishi:

Empty-handed I go and yet the spade is in my hands;

I walk on foot, and yet on the back of an ox I am riding;

When I pass over the bridge,

Lo, the water floweth not, but the bridge doth flow.

6

Merwin's “It is March" begins with images of "absence":

It is March and black dust falls out of the books

Soon I will be gone

The tall spirit who lodged here has

Left already

On the avenues the colorless thread lies under

Old prices

When you look back there is always the past

Even when it has vanished

But when you look forward

With your dirty knuckles and the wingless

Bird on your shoulder

What can you write

Vanishing, the world suffixable with -less, and the final line "Whatever I have to do has not yet begun." It invites comparison with Rilke's "Herbsttag":

Who has no house now will not build him one.

Who is alone now will be long alone,

Will waken, read, and write long letters

And through the barren pathways up and down

Restlessly wander when dead leaves are blown.

7

When you seek the Buddha, you cannot see him: when you look for the patriarch, you cannot see him. The muskmelon is sweet even to the stems, the bitter gourd is bitter even to the roots.

(Goso Hōyen)

It begins austere, but it's sensuous, it's witty, it's serious. What is not visual does not minimalize what is. It's not metaphysical propaganda. 
Saying no or absent or dark with warmth in the voice is an art, eastem or western. Henry Vaughan could do it:

There is in God (some say)

A deep, but dazzling darkness; as men here

Say it is late and dusky, because they

See not all clear;

$O$ for that night! where I in him

Might live invisible and dim.

("The Night")

9

... the Mexicans are on a more familiar footing, as it were, with death than any other peoples in the world. In their folk-art we find death depicted in many forms: as a marionette, as clay figures, and in pictures. The bakeries bake "death bread." The confectioners make ornate death's-heads of icing. In Toluca toys are made which represent coffins, out of which a corpse bobs up when the lid is opened. Another extremely popular depiction of death is the funeral procession, complete with open coffin, which is mounted on scissors so that one can set the procession in motion.

(Gerd Dörner, Mexican Folk Art)

10

The divine is not human; it is something quite different. And it is not noble or sublime or spiritualized, as one likes to believe. It is alien and repellent and sometimes it is madness. It is malignant and dangerous and fatal. Or so I have found it. . . . [God's son] must have come into the world just to show that meaninglessness, too, is divine. . . . I don't know who [God] is. How then can I hate him? Or love him? I believe I neither hate him nor love him ... it seems to me that such words have no meaning when applied to him. He is incomprehensible, inscrutable. He is god . . . he is both evil and good, both light and darkness, both meaningless and full of a meaning which we can never perceive, yet never cease to puzzle over.

(Pär Lagervist, The Sibyl)

That puzzling is precious. While we puzzle we erase neither the yesses nor the nos. 